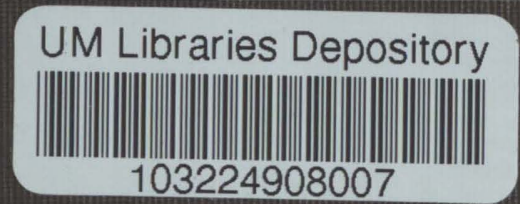




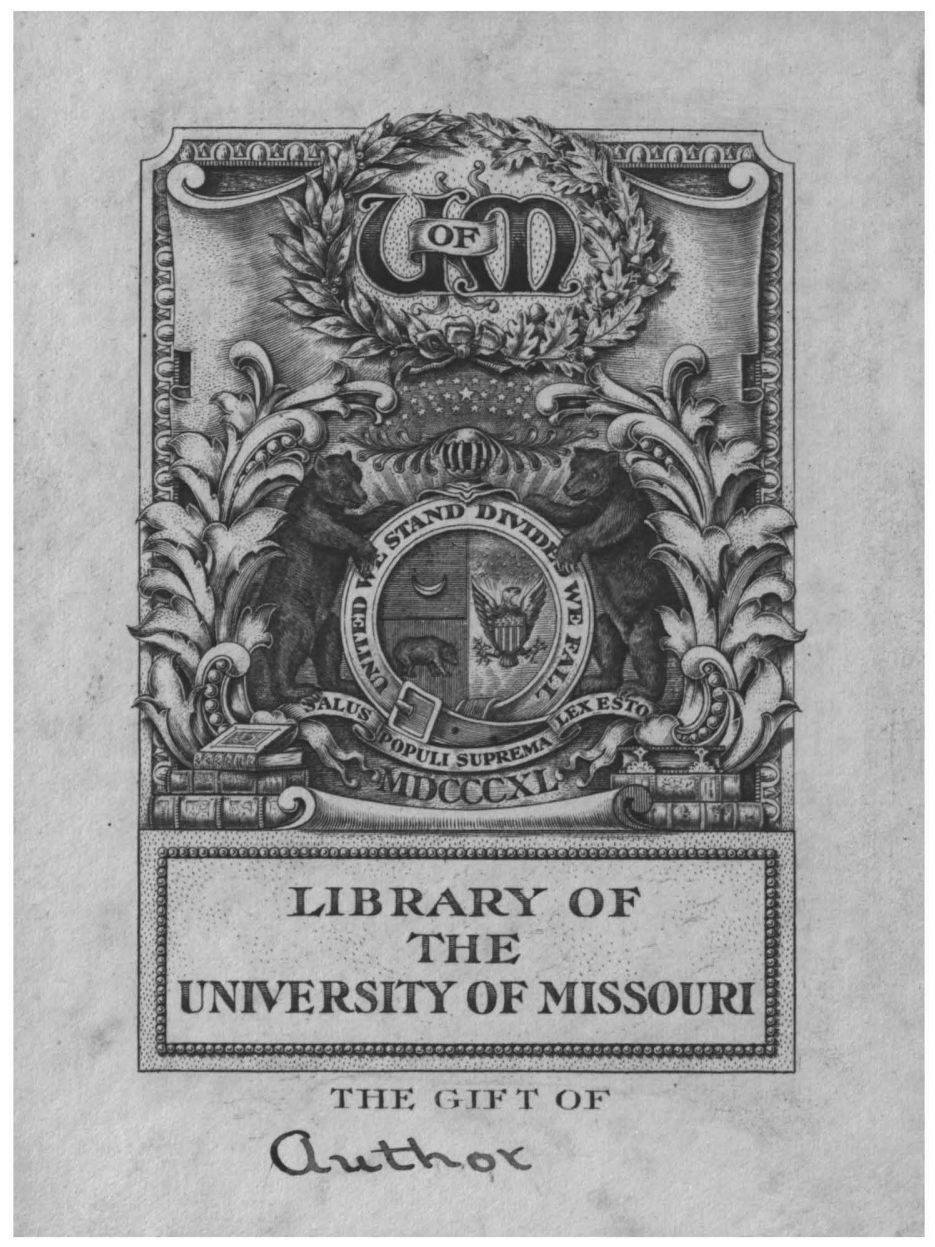

This Thesis Has Been

MICROFILMED

Negative No. T. 






\section{THE GODS OF THE AENEID}

\section{A Thesis Submitted for the A. M. Degree}

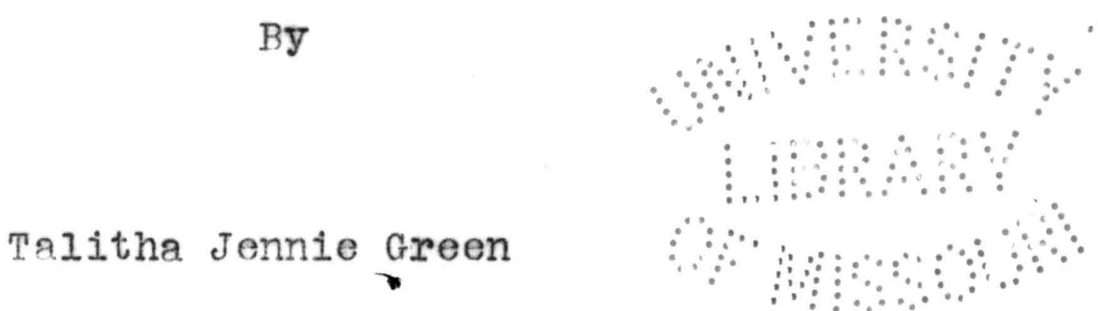



$378.7 M 71$

$\times G 82$

THE GODS OF THE AENEID.

Index

Jupiter.

Pages

Apollo $\checkmark$

$1-7$

Juno $\checkmark$

$7-10$

Venus $\checkmark$

10-15

Diana $\checkmark$

15-17

Minervav

$17-19$

Vulcan $\checkmark$

19-21

Neptune $\sqrt{ }$

$21-22$

$\operatorname{Mars}$

$23-24$

Pluto and his Kingdom

$24-25$

Mercury

25-29

Bacchus

29

Penates, Lares, Vesta

$29-30$

Fata and Parcae

30-31

31-32 

JUPITER

Jupiter, the father of the gods and the king of men (I 65 divum pater atque hominum rex), was the son of Saturn (Saturnus pater IV 372) and Berecyntia (IX 82 fertur genetrix Berecyntia---Jovem, 93 filius huic). Crete was his island, for it was there he was concealed when a babe (III 104 creta Jovis---insula)

' By the help of his mother (IX 84 tua cara parens domito te poscit 0lympo) he drove Saturn from 0lympus, took up his abode on the mountain and was ever after known as the ruler of 0lympus. (VIII 319-320 ab---venit saturnus 0lympo arma Jovis fugens et regnis exsul ademptis

V 533 rex 0lympi, II 779 regnator 0lympi)

The sons of Aloous made an effort to dethrone Jupiter, but were unsuccessful and were cast into Tartarus. (VI 582-584.)

Jupiter once had a struggle with the hundred-armed monster Aegeon who vomited out fire from fifty mouths to match Jove's lightning and flourished a sword in each of his hundred hands(X 565-568.) Homer represents this monster as having helped Zeus when all the 0lympian gods were against him(I1 I 400-405.)

Zeus was the son of Kronos and Rhea, (II XV 187, IV 205, XVI 43I) and Vergil identifies Kronos with the Italian god Saturn. Neptune and Pluto were brothers of Jupiter (V 799-X 113,) and Juno his sister and wife.(I 47.) 

Jupiter had a palace and a golden throne on 0lympus (X 1 , domus omnipotentis 0lympi, X 116 solio Juppiter aureo) from whence he ruled earth and sky at his will (III 21 caelicolum regi, IV 268-9 me---demittit 0lympo regnator, caelum et terras qui numine torquet).

With his rod he shook 0lympus (IX 106 totum nutu tremefecit 0lympum, ditto X 115). At his word the gods were mute, the earth trembled, the winds ceased their flight and the waves rested (X 101-103), His lightnings terrified (I 230) for sometimes they were sent by the angered father to scathe those whom he had often honored (II 648); sometimes they sent the offender down to the shades (IV 25, V 691) The leech paeon was slain by lightning because he presumed to bring back to life one who had gone down to Pluto (VII 770-773).

Jove's deadly barbs were made by the cyclops in Vulcan's workshop. The materials were three rays of forked hail, three of rain cloud, three of glowing fire and three of the winged southern blast; with these were mingled a terrible glare, noise, fright, wrath and glowing flame (w1 422-432). What presumption for any mortal to try to imitate such bolts! Yet Salmoneus made the attempt. He claimed for himself the honor of a god and with his brazen car, his smoking pine torch and the clattering of his horses' hoofs he was trying to imitate thunder and lightning when a real bolt from Jupiter sent him 

down to Tartarus (VII 585-594.)

It is the vengeful bolt of 0lympus that makes treaties binding and inviolate (XII 200 genitor qui foedera fulmine sancit.) but Jove's own vows to be reliable must be sworn to by the Styx (IX 104 Stygii per flumina fratris, $\mathrm{X}$ 113, ditto).

But Jupiter was not always in anger. He smiled and the skies cleared and the tempest ceased (I 255 subridens---sator---vultu, quo caelum tempestatesque serenat).

His thunder sometimes sounded in token of answered prayers. Anchises prayed about the sign on Iulus' head and there was thunder on the left and a meteor flashed across the sky (II 693-698). In gratitude Aeneas prayed and three times there came thunder from a clear sky, and a glowing cloud was held up to his view. (VII 14l-143).

In answer to Aeneas ' prayer for the ships not to burn, there came thunder and a pouring rain ( $\nabla$ 693-696.) When Julus promised yearly sacrifices to the lord of the southern blasts, it thundered on the left, though the sky was serene. (IX 626-634,670) When Jupiter shook his dark aegis, and gathered up the clouds, the rain came upon the earth (VIII 353-354.)

In Vergil the left was the favorable side for omens, while with Homer it is the right (II. II 353, IX 236.)

The eagle was Jove's bird and its presence was recog- $v$ nized as an omen from him. (I 394 Jovis ales, V 255 Jovis armiger, IX 564 ditto, XII 245-260.) 

0aks and cypresses were his trees. (III 680-581.)

He was worshiped with libations and sacrifices (I 729, VII 133, pateras libate Jovi precibusque vocate.) Snow-white bulls seem to have been especially pleasing to him. (III 21 nitentem-mactabam---taurum. IX 627 juvencum candentem.)

Homer represents Zeus as specially pleased with fiveyear-old bullocks II II 403, VIII 315. Iarbus reared one hundred temples to Jove, and kept the fires ever burning on the altars and the ground rich with the blood of victims. (IV 199-202.) For such devotion his prayer for the thwarting of his rival's plan was heard. (IV 220.) In time of urgent need Jove could be called upon without a sacrifice (II 689; V 685, VIII 560, X 875, XII 178.) Jupiter knew the future (I 254-296.) but by prayers and suplication he could be moved to change it. Vulcan said Jove and the fates would have allowed the walls of Troy to stand and have given Priam life for another ten years if Venus had asked it. (VIII 395-399.)

Juno prayed Jupiter that 'Latin neme, language and manner of dress remain unchanged by Troy, and she obtained her request. (XII 822-833.)

Sometimes Jupiter laid down all power and left everything to fate. (X 107-113.) Though ruler of the affairs of mon, he seoms not to have been entirely independent of fate, for when Aeneas and Turnus were struggling he poised the balance in his hand to see which of the two was fat.er t. 

Although often called allpowerful, the gods wrangled against his will and brought on a struggle between Trojans and Latians against the decree of the allpowerful (X 6-10, 106.) In fear of the power the winds might exercise, Jupiter put them in a cave and placed a powerful ruler over them (1 58-62.)

Palinurus doubted the absolute power of Jupiter, for when a storm came up he said he couldn't hope to reach Italy during such a gale, not even if Jupiter should promise a safe passage ( V 12-18.)

Cupid was able to disregard the terrible weapons of Jove, but of gods or men there was no one who so often eluded the allpowerful one as his own dear wife (IV 91, $V$ 783-784.) He was aware that she often deceived him, and when about to grant her a request he warned her not to have in her heart some meaning deeper than the words of the request implied ( $X$ 625-627.) He, the ruler of earth and sky prayed his wife to listen to his request, to grant his wish and lay aside her wrath (XII 793-802.) When he had promised her rewards that she thought sufficient to justify her in laying aside her wrath, she yielded to his prayer, but not before. (XII 833-841.)

TITLES

Pater omnipotens I 60, III 251, IV 25, VI 592, VII 141, 770, VIII 398, X 100 Divum pater atque hominum rex. I 65 , II $648, \mathrm{X} 2$, 



\section{$\times 743$}

Deum pater X 875.

Res hominumque deumque-regis. I 230

Hominum sator atque deorum I 254.

Rex magne I 241

Deum rex III 375 XII 851.

Jove Surmo I 380 VI 123

Patris surmi I 665

Patris Magni IV 238, IX 495

Pater II 617, 691, V 690, X 18

Regnator doum IV 268

Hospitibus-- tedare jura I 731

Morem ritusque sacrorum adiciam XII 836

Juppiter omnipotens II 689, IV 206 V 687 IX 625

Regnator 0lympi II 779

Rex magnus 0lympi V 533

Regi caelicolum III 21

Omipotens IV 220

Juppiter auctor V I7

Pro Juppiter, aspanpath, IV 590

Aequus Juppiter VI 130

Idaeum Jovem VII 139

Gentitor VIII 427, IX 630, X 466, 668, XII 200, 843

Hominum rerumque aeterna potestas X 18

Rerum cui prima potestas X 100

Ferus Jupiter II 326.

Saturnius pater IV 372 

Rex aetheris altus XII 140

Rex Omnipotentis Olympi XII 791

Magnantimi Jovis XII 144, 878

Hominum rerumque repertor XII 829.

PHOEBUS APOLIO

Apollo and Diana were twins of Jupiter and Iatona. (XII 198 Latonaeque genus duplex.) The brother and sister were often worshiped in the same temple. (VI 9-13,35 Phoebi Triviaeque sacerdor X 537.)

Out of the gratitude for the shelter that the floating island of Delos gave to the fugitive Latona, Apollo bound the island and made it stable (III 75-77. IV 144. Delum maternam.) The island was always dear to him and there was his Ortygian shrine (III 154, 143.) Lycia was called the land of Apollo. (XII 516 Lycia missos et Apollinis agris. IV 143 Lyciam-deserit---Apollo, 346,377.)

Whon Apollo came down from Lycia to Delos a chorus from neighboring Crete met him and people from $\not i s t a n t$ Scythia gathered to dance about his altars. The god moved majestic on Mt. Cynthus, adjusted his long light hair (IX 638 crinitus Apollo, 651 crines albos,), crowned it with a graceful wreath and entwined it with gold. From his shoulder swung his bow and arrows (IV 143-149.) He was the handsome Apollo, the type of manly beauty (III 119 pulcher Apollo.)

Apollo was the revealer of the future and was worshiped in Troy, Delos, Mt. Leucate, Cumae and Laurentum 

(II 114-118, III 79, 143, 275, 359, VI 9, VII 59-73).

The door of Apollo's temple at Cumae was a wonderful piece of work from the hand of the a tificer Daedalus. It was at Cumae that Daedalus lighted after his wonderous flight and there he built a temple to Apollo and dedicated his wings to him (VI 12-33). Near his temple was the Sibyl's cave with its hundred mouths to utter forth the oracles of the god. Apollo had to ply the goad and subdue the ferocious spirit of the Sibyl before she would speak his prophecies. (VI 41-51, 98-101). The tripod, the sacred laurel, the temple and even the mountain trembled at the power of the god. (III 90-92). The meaning of the oracle was not clear, and a misinterpretation sometimes resulted seriously. (III 154-162).

Apollo received his prophetic powers from Jupiter, and shared them with priests, the Sibyl, household gods of Aeneas, and the harpy Celaeno. (II 114, 121, III 154-162) 359-361, 251, VI 12.)

From Apollo came the ability to read the stars and to understand the language and flight of birds, augury, skill in the use of the bowa lyre, and knowledge of medicine. (III 359-361, XII 391, 394, 402, 405).

It was Apollo who guided the dart that pierced Achilles' heel (VI 57-58.); Arruns prayed him to guide the arrow sent against Camilla (XI 789-793); Ascanius' success in his first battle was the gift of Apollo. (IX 655 pri- 

mam hanc-...Apollo concedit)

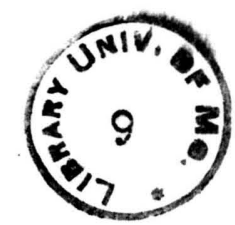

The arrow and the lyre were attributes of Apollo (IX 659,660, VI 662, XII 394.) The laurel was his tree (VII 59-64), and his priests adorned their brows with laurel wreaths (III 81, 91, 360.) Bulls and two-year-old ewes were sacrificed to him (III 119, 369, VI 38,39.taurum tibi, pulcher Apollo, caesis juvencis-...exorat Juvencos-... totidem bidentes.)

Apollo had the gift of healing and the power to bring pestilence on man and beast, or to send Sirius to parch the crops and trees. III 139-142.

The name Phoebus is indicative of Apollo as sun-god. Phoebus bathed his tired steeds in the Hiberian sea, and ushered in the night (XI 913-914). It was Phoebus' lamp that Aurora used for lighting the earth (IV 6 Phoebea lustrabat lampade terras-..-Aurora)

Vergil seems to have identified Phoebus with the Ital ian sun-god, Sol. Not far from Carthage Sol yoked his horses (I 568). They rose from the deep sea, and breathed out light (XII 115); they carried Sol aloft from whence he viewed all things on the earth (IV 607).

The horses of Aeneas were once the property of Sol, and were stolen by Sol's daughter Circe and given to Aeneas (VII 10, 282). Latinus wore on his brow twelve golden rays, the gift of his ancestor Sol (XII 161-164).

Phaeton, as well as Sol, seems to have been confused with Phoebus Apollo (V 104-105.) 

Pine wood fire was sacred to Apollo and his worshipers walked on live coals, secure in his favor (XI 786-788). Apollo was the friend of the Trojans but Vergil makes no mention of his having assisted at the building of the walls of Troy. Homer assigns the burning of trees and meadows, and the destruction of fish and eels, not to Apollo, but to Hephaestus (III 139-142. Il XXI 335.)

TITLES

Arquitenens III 75

Thymbraee, III 85.

Clarii III 360

Gryneus Apollo IV 345

Delius Vates VI 12

Actius Apollo VIII 704

Custos Soractis Apollo XI 785

Pater---omnipotens XI 789-790

Deus Auctor Apollo VIII 336, of Evander

Auctor Apollo XII 405 , of physician Japes

Phoebus Apollo III 251.

JUNO

Juno, queen of gods (divum---regina I 46) was the daughter of Saturn (Saturna I 23, Saturni---proles XII 830) and sister and wife of Jove (Jovisque et soror et conjunx I 46-47.)

The titles she bore and the adjectives applied to her give an idea of her character:

Saeva Juno I 4, VII 592.

Saturnia VII 560, I 23 X 659, VII 622 

Saturnia Juno V 606, III 380, IXZ2, 745, 803 X 760 XII 156 Regina I 76, 46.

Regia Juno I 443, IV 114, VII 438, X 62.

Atrox Juno I 662.

Iniqua Juno I 668, VIII 292.

Juno saevissima II 612

Magna Juno III 437.

Argivae Junoni III 547.

Cara Jovis conjunx IV 91.

Conscia Juno IV 608.

Aspera Juno I 279

Omnipotens Juno IV 693.

Gravis Juno V 781

Saeva conjunx Jovis VII 287

Magna Jovis conjunx VII 308

Horrenda VII 323

Omnipotens Saturnia VII 428.

Saturnia regina VII 572.

Infelix VII 309.

Gabinae Junonis VII 682.

Maxima Juno VIII 84, X 685.

Dura conjunx X 44.

Germana atque gratissima conjunx X 607.

Juno submissa X 611

Sa.turnia dea XII 807.

Juno was intensely human in her passions, as shown by her hatred of the Trojans. She had three grievances against the Trojans: the slight to her beauty by Paris' 

decision; the dismissal of her daughter from the office of cup-bearer to the gods, in favor of a Trojan youth; the stealing of the queen of her beloved Argos by a Trojan prince (I 26-28.) She could never forget her wrath, and neither time, prayers, fate nor Jove's command could stay her vengeance (V 783-784.) She moved earth, sea and sky, the gods above and the powers below against the hated remnant. (I 279-280 V 783-784.) She recalled what Pallas (I 39-47) and Mars (VII 304-308) had been able to do against those they hated, and reasoned that she, the wife of the great Jove ought to be able to do more. She feared that if she could not subdue one poor remnant of a race no one would worship her power or adorn her altars(VII 331-334, I 46-49.)

Juno was not, without friends who were willing to aid her. She had the assistance of Aeolus god of the winds, (I 65-77), of Alecto, the most obnoxious of the realm of Tartarus (VII 324-340), of Juturna a river nymph (XII 142153), of Iris (IX 2, IV 694, V 606), and of Jove (X 621627. XII 833.)

Her own powers were vast and varied. She declared war (VII 572-573), with her own hands smote the iron bars of the gate of Janus (VII 622), and all things of the war went at her nod and beck . (VII 592). Begirt with a sword and raging she collected the Greeks at the wall of Troy (II 612-613.) 

She gave strength and power to those she wished to be victors (IX 764); she turned aside the weapon aimed at Turnus (IX 745-746). She commanded that the treaty of peace to broken at her responsibility (XII 158-159). She had Eurystheos put Heracles to his labors (VIII 292.)

Juno was a prophet ( $I$ 443), and could restrain the prophetic powers of another (III 380). She had propitiated Jove and granted Aeolus the kingdom of the winds. (I 76). In return for a favor granted by Aeolus she promised him one of her fourteen nymphs for a wife(I 71.)

Juno was the goddess of the marriage bond, and in this capacity she was worshipped with a sacrifice of ewes (IV 57-59), and her presence was implored where love was to be won (I 734). Aeneas' marriage displeased her, and the prece of her displeasure was the blood of two nations (VII 318). Aeneas, obedient to the prophet and the river god (III 437, VIII 60), tried to appease Junp with sacrifices, even pouring out on her altars the blood of the white sow which appeared to him as a prodigy (VIII 82-84). The places favored by Juno were Samos ( I 16), Argos (I 24, III 547, VII 286) and Carthage (I 15, 16, 446.) There was a great temple to her in Carthage and another in Troy (II 76I), where the youths fled for protection.

The dear wife of Jove (IV 91) knew when she could with impunity disregard her lord's commands. She did not lay aside her wrath when he commanded ( $\nabla$ 784), but was 

obedient when the order came with a threat (IX 803).

Jove's rebukes were couched in mild terms, and he addressed her as "sister and most charming wife" or as "sister, and the other offspring of Saturn" (X 607,XII 830). She replied submissively, with professed fear and real tact, addressing him as " most gracious husband" ( $X$ 611) and in consequence obtained her request ( $X$ 622). But Jove knew her character and warned her to beware of deceit and not to have some deeper meaning hidden under the wording of her request ( $X$ 625-626). Perhaps Vergil had in mind what Homer relates of the difficulties that arose between leus and Hera about the birth of the son of Sthenelos. (II XIX 97-120).

Jove tried to appeal to her sense of right, reminded her of the trouble she had caused, and with prayers begged her not to let her sweet lips give utterance to her rage (XII 796-800). She obeyed, and in reply asked a favor, which Jove granted, smiling at her persistency and the great waves of anger that rolled in her soul (XII 829-840).

Juno appears always and only as an evil spirit which pursues the Trojan remnant. She has not a many-sided character. She has some of the baser elements of human nature highly developed. Hera has a broader character, many more elements in her nature, and hence is more human and more real. Juno is never pleasing, is lacking in all the feminine charms with which Homer clothes Hera. It would be difficult to find two pietures of greater contrast 

than the one representing the enraged Juno seeking aid of the most hideous of the furies (VII 291-340), and the one of the bewitching Hera attired in all her beauty and with the enchantment of Venus, going to pay a visit to her lord (II XIV 161-343)

Zeus' rage at the conduct of his wife is much greater than that of Jupiter. Zeus says nothing is more unabashed than Hera, that she is hard to deal with, and threatens to beat her with stripes and on one occasion punished her so severely that all the gods had compassion on her. (II XV 14-22, VIII 483). Jupiter beseeches and entreats, tries to reason with Juno. XII 796-800.

\section{VENUS}

There are two myths concerning the origin of Venus. According to one she sprang from the sea-foom (V 800-801): according to the other, which Vergil follows, with one exception, she was the daughter of Jupiter and Dione (I 250, 256, III 19, X 16, 30,62). She was the wife of Vulcan (VIII 372,377), and of the Trojan Anchises (III 475).

From the marriage with Anchises sprang Aeneas (I-664, 665, 698, 720, I-94). When Venus appeared on earth clad in the beauty which she wore at the court of heaven, her brilliancy was sufficient to light up the darkness of the night (II 589-591). Once she appeared in the disguise of a Spartan maid, and Aeneas mistook her for a nymph or Diana, but her deep sympathy with his' sufferings, her rose-tinted neck, her hair fragrant with ambrosia, and the graceful 

flow of her garments soon revealed his goddess mother. (I 314-329, 402-406). Sometimes she sought Aeneas' embrace, or grasped his hand (VIII 615, II 592); again she eluded his touch and vanished in a cloud (I 408-4l2).

With all a mother's love Venus tried to shield her son from the wrath of Juno. She used her own power, particularly as goddess of love, and sought aid of the other immortals. She gave Aeneas the appearance of a god and sent Cupid to aid him in winning the love of Dido (I588593, 657-660). When Vulcan hesitated to grant her request, for armor she exerted the influence of her love and in conscious beauty smiled at her power (VIII 370-404).

Vulcan said that Venus' power was so great that had she made the request Troy would have been spared and Priam given ten more years of life (VIII 395-399). It was her power in love that enabled the Trojans to overcome Turnus and his band $(\mathrm{X} .608,609)$.

Harassed with cares Venus sought help from Neptune and he assured her it was quite right for her to come to him for aid in as much as it was from his realm that she took her origin $(V 779,800,801)$.

Sad and weeping at the evils Juno sent, Venus sought help from Jupiter. In a fatherly way he smiled upon her, kissed her lips and spoke words of comfort and promise. X 16-62, I 256-296.

She had power to give a sign in the heavens, a glare, and the sound as of a bellowing trumpet resounding again 

and again, making all nature tremble (VIII 523-527). By means of a healing herb gathered on Mt. Ida, she effected the cure of Aeneas' wound. (XII 4ll-424)

Venus became indignant at the audacity of a seanumph who disobeyed Jupiter's order, and then with human inconsistency, she herself disobeyed the same order (XII 786-790)

The birds of Venus were the swan and doves (I 393-400, VI 190-203). The myrtle was sacred to her and Lucifer was her favorite star. (V 72, VIII 590).

Amanthus, Cythera, Paphos and Idalium were her favorite resorts (X 51, 86, I 693, XII 412): At Pakchos she had a temple, and one hundred altars smoked with Sabean incense and were kept fragrant with fresh garlands (I 415417).

wass

Venus called Cytherea (I 257,657, IV 128, V 800, VIII 523), the Acidalian mother of Cupid (matris Acidaliae I 720), the Phrygian mother of Aeneas (Phrygiamque-..-matrem VII 139), the Idalian Venus (Veneri Idalia V 760), and Dionaean mother (Dionaeae matri III 19). The adjectives candida (VIII 608), aurea (X 16), alma (II 591,X 332), and pulcherrima (XII 554) are used in describing Venus.

Vergil nowhere uses the descriptive adjective that Homer so often applies to Venus, "laughter loving" DIANA

Diana was the twin sister of Apollo (Latonaeque genus duplex XII 198) and in many respects his feminine 

counterpart.

She was a virgin goddess and the guardian of groves (nemorum cultrix, Latonia virg XI 557, lucAs---Dianae III 681, Triviae lucos VI 13, Triviae luscisque VII 778, nemorum Iatonia custos IX 405).

She roamed the forests as a huntress, and hunters prayed to her for success in the chase and gave of their game to hang from the roofs of her temples or adorn her towers. (I 329 IX 406-408). Calydon was laid waste because its ruler failed to pay honor to Diana when he sacrificed to the other dictios (VII 306-307). Sometimes Diana came down to the banks of Eurotas or stood on the top of Mts.Cynthus and led the dance of a thousand nymphs. Her quiver hung from her shoulder and she moved majestic among the throng of nymphs and goddesses, taller than any other of the group (I 498-502).

With the aid of a leech Diana, much to Jupiter's displeasure, brought back to life one of herfavorites. To save the favorite from a second death she hid him away in her secret haunts in Egeria (VII 764-778). Camilla, one of the fiercest of the Trojans' antagonists, had been consecrated in childhood to Diana and as a maiden refused all offers ofmarriage puferring to be a follower of the virgin Diana. Though Diana's love and weapons could not stay Camilla's death, they avenged it.

The goddess herself came down to earth in a cloud and bore away the bedy and armor (XI 535-594, 845-857). 

Diana was often called Trivia, perhaps because of the three forms she assumed, Diana on earth, Luna in heaven and Hecate in Erebus. (VI 13, 35, 69, VII 778, 774, X 537, XI 566). Dido prayed to the triple Hecate (IV 511 tergeminamque Hecaten, tria virginis ora Dianae), and to the Hecate who was invoked through cities at the cross-roads during the darkness of night (IV 609 nocturnisque Hecate triviis ululata per urbes). Hecate placed the sibyl in charge of the Avernian grove about the temple of Phoebus and Diana (VI 118, 564).

The lofty Luna was the glory of the stars, the Iatonian keeper of the green-wood, and was worshiped with hunter's gifts and asked to guide their arrows. (IX 403407. The shining eye of Polyphemus was compared to the orb of Phoobe. (III 637 Phoobea lampadis instar). When day had gone from the sky kind Phoebe drove her nightly car over lofty 0lympus(X 215-216.)

\section{MINERVA}

Minerva waspowerful in arms and presided over war (II 425 divae armipotentis, XI 483 armipotens, praeses belli ). Her armor was made in Vulcan's workshop. The bristling aөgis was adorned with gold and scales of serpents. On the front was the Gorgon's head with its serpent locks and eyes rolled up in death (VIII 421, Vulcani domus, ,-.- 435-438. II 615-616). Minerva was most proficient in the feminine arts of spinning and weaving (V 284, serva---hated ignara Minervae. VIII 409 

femina---cui tolerare colo vitam tenuique Minerva). She was the giver of wisdom, understanding and skill (v 704-705 Pallas----docuit multaque insignem reddidit arte. It was by the cunning of Pallas that the Argives built the wooden horse (II 15 divina Palladis arte.) Two Greeks had stolen the Palladium from her temple and with blood-stained hands had defiled the sacred effigy. Pallas was justly angry at the Greeks, and the Trojans readily believed that the horse had been made to propitiate her. They were prompt to ascribe Iaocoon's death to his sin against the consecrated horse (II 15-183, 230).

Pallas'anger at the Greeks did not gain revenge until Roman times (VI 838-840.)

Pallas had some of Jove's power in hurling thunderbolts. In her anger at Ajax she hurled the rapid lightnings from the clouds and sent the winds to toss up the sea. The victim of her rage was impaled on a sharp craig and pierced through the breast (I 39-45).

Vergil refers to the virgin goddess as often by her Greek title Pallas as by the Roman name Minerva. (Pallas- I 39, II 15, 163, 615, III 544, V 704, VII 154, VIII 435, XI 477, Minerva- II 31, 189, 404, III 531 V 284, VI 840, VIII 409, 699.) Another one of her titles is Tritonia (II 17 RR, 615. V 703 XI 483).

The Athene of Homer engages in hand to hand struggles with the other gods. She hit Ares in the neck 

with a huge stone, knocked him down, then laughed about it. With her hand she knocked down Aphrodite (II XXI 395-414).

According to Homer it was Athene who caused Diomde to wound Aphrodite in the hand (II V 129-134) Aen XI 269 277).

\section{VULCAN}

As Jupiter was the "omnipotens" ( I 60), Minerva and Mars the "armipotens" (II 425 IX 717), Vulcan was the "ignipotens", the powerful master of fire. (VIII 628, $X$ 243, XII 90). His name was a synonym for fire. (II $311, V 662$ VII 77).

Vergil once calls him by the name Mulciber (VIII724)

Venus, the wife of Vulcan, wished a favor from her lord. She sought him as he reclined on his golden couch, reminded him of the favors that other women had obtained from him-Thetis the armor for Achilles, and Aurora her request-wound her snowy arms about him, beguiled him with her charms and smiled to think that the fires she kindled were of such a kind as to conquer the lord of fire. Vulcan assured her of her power over him and said that, had she requested it, he would have made armor for the Trojans, and Jupiter would have allowed Troy to stand and Priam to live (VIII 370-399.) Was this true? Did Vulcan have such power, or was it a wild promise made under the spell of love? True or false, Vulcan was a powerful god and all his skill in iron and gold, in fire and winds was placed at the ser- 

vice of Venus (VIII 400-404).

With the coming dawn, Vulcan sprang up from his couch, descended from the sky and came to his workshop under Mt. Aetra. The rocks of the island smoked, the cave resounded with the thundering strokes of the Gyclops and the fire leaped from the furnace. This was the centre of of Vulcan's labors and the land bore his name. He found the Cyclops making thunder-bolts for Jove, a war car for Mars and an aegis for Minerva. He ordered all hands to assist in making the armor that Venus had requested. Gold, copper and iron were poured into the furnace; tongs bellows, anvils and hammers were in use (VIII 414-453). Vulcan himself endowed with a presistent mind, engraved on the armor much of the future history of Rome (VIII 628-728).

The fire-vomiting monster Cacus was a son of Vulcan (VIII 198-280).

Vergil assigns Vulcan's workshop not to Olympus (II XVIII 142-143, 369-371) but to a cave under Mt. Aetra. (VIII 414-420).

According to the Iliad, Charis was the wife of Vulcan (II XVIII 382-382), but the Odyssey and Vergil give Venus (Aen VIII 370-372). 

NEPTUNE

Neptune was a son of Saturn and a brother of Juno and Jupiter (V 799 Saturnius domitor, I 130, fratrem Junonis).

By lot the sea became his realm and the trident the emblem of his power. (I 138-139, VIII 695).

When he yoked his steeds to his gold and sea-green car, put the foaming bits into their fierce mouths and glided over the surface of the sea, the waves subsided under his thundering axle, the clouds scattered from the sky, and sea-nymphs, Tritons and monsters of the deop followed in the wake of their king ( $V$ 817-826)

The winds were threatened with an inexpressible punishment for having usurped authority and caused an ocean storm, and wrecked Aeneas' ships. (I 135)

Neptune raised his powerful brow above the water, scattered the clouds and sent aymothoe and Triton to drag the ships from the rocks. With his trident he oponod up a passage through the shoals (I 126-153) Although Neptune had built the walls of Troy (II 625, III 3, V 811, IX 145), he aided in their down-fall. On the day Troy fell he was seen with his trident shaking the walls and foundation of the city (II 610. Neptunus muros magnoque emota tridenti fundamenta quatit). But he had no malice toward the band of Aeneas. He snatched away Aeneas in a cloud and saved him from 

Achilles (V 810 Aenean---nube---r rapui): he quieted the storm that Juno sent a gainst the Trojan fleet (I 126155): he savedthe fleet from being draw aside by Circe's enchantment (VII. 23), and gave a safe passage to Italy (V 863).

Neptune was the giver of victory in the boat race (V 195 Neptune, dedisti). Palinurus recognized Neptune as the cause of the dark and stormy night at sea. (V 13-14).

Delos and Aegaea were dear to Neptune (III 74).

Altars and temples were erected in his honor and bulls were offered to him (V 360,640, III 119, V 235) Laccoon was offering a snow-white bull when the prodigy of the serpents occurred(II 201).

\section{MARS}

The Mars of Vergil is far from having the personality of the Ares of Homer. By Vergil the name Mars is often used with no idea of personification, merely a synonym for war, struggle or conflict. (II 335, \#I 165, VII $540,550,582$, VIII $495,516,557,676$, IX 518,766, X 237, XI 153, XII 108, 187, 712, 790).

In other instances Mars is the god of war, and some of his attributes are given (XII 179), The Cyclops made his chariot and swift wheels with which he maddened individuals or communities. (VIII 433-434). Along the banks of the Hebrus the bloody god thundered on his shield and hastened his steeds that flew more swiftly 

than the winds.

Thrace resounded beneath the tread of his horses. Anger, treachery and panic were his attendants (XII 330-336. Formidinis ora Iraeque Insidiaeque).

Sometimes with an impartial hand he dealt an equal lot to all (X 755): by his lot certain ones had to die (XI 110): all-powerful in arms (IX 717) he gave strength to one side and cowardice to the other: if he was adverse)discouragement followed (XII 1): he was said to sit on the hand of the brave (X 280. In manibus Mars): he was fierce, hard-hearted and cruel (XI 153, XII 73, 410)

Mars was called Gradivus, and under this title a suit of armor taken in battle was consecrated to him (X 542). Gradivus presided over Thrace (III 13, 35) The name Mars is frequently modified to Mavors, in noun or adjective form. (I 276, III 13, VI 777, VIII 700, XII 179, 332).

Rome was called a Mevortian city beeause founded by Romulus a son of Mars(I 276, VI 872).

Vergil makes mention of the twin off-spring of Mars and of their nurture by the wolf (VI 777, VIII 630, IX 566).

\section{PLUTO AND HIS KINGDOM}

Pluto was the brother of Jupiter and the ruler of the kingdom of the dead. His wife Proserpine shared with him the duties and honors of ruling (X 113 Stygii-.. 

fratris VI 402, 138, 142). Proserpine was the niece of Pluto, and an unsuccessful effort had been made to steal her away from him (VI 395-402).

Minos and Rhadamanthus were judges of the dead (VI 432 Quaesitor Minos, 566-569). The furies, Alecto, Tisiphone and Megaera had their abode in Eberus (VII 324-329, VI 570-574, XI 846).

According to Vergil and the Iliad the abode of the dead was beneath the surface of the earth. (II IX 568, XXII 482, XX 61, Aen IV 446,660, VI 98-106, 128, 23\%). According to the Odyssey the region was far to the west on a low lying island (0d. X 508). The region under the earth was bounded by terrible rivers: the Styx, a river sacred among the gods, and by which they swore and feared to break their oathes (VI 323-324): the Acheron, river of woe (V 99, VI 107, 295): the Cocytus, river of vrailing (VI 132, 297, 322): the Phlegethon, river of fire (VI 265, 551).

The regi on was inaccessable to the living (VI 154 regna invia vivis). A few descendants of the gods had been permitted to enter while living, being especially loved by Jove or very remarkable for valor (VI 129-130) The way down was easy, the gate open day and night, but to retrace onés steps was seldom possible. (VI 126-129) The living man who sought entrance had to find a golden twig to carry as a Sacred gift to Queen Proserpine 

(VI 137-142) When Aeneas was about to descend he sacrificed a black ewe lamb to the mother of the furies, a barren heifer to proserpine, and whole black bulls with oil poured on, to Pluto. (VI 153, 249-254).

Before the vestibule were Grief, Crime, Disease, Death and monsters of every description.

According to Homer it was the duty of Hermes to conduct the dead to Pluto, but Vergil has the ferryman Charon meet them with his grim barge at the banks of the Styx and conduct them across. Charon would not take a soul across unless the body, condermedthe soul to wander longingly about the banks of the Sty for a hunared years before it could cross. (VI 299-330) (Od.XXIV 1-9)

Once over, the soul was confined by the Styx rolling nine times between it and the farther bank (VI 439)

The inhabitants were arranged in groups: those who had died in infancy (VI 427); those who died under false accusation and were tried by Minos (VI 430-433); those who had tired of life and committed suicide; those who died of love; and in a field apart, the renowned warriors (VI 437, 442, 478). Beyond the field of warriors the path divided, one part lead ing under Pluto's great walls to Elysian fields, and the other to Tartarus the abode of the wicked. (VI 540-543) A triple wall and waves of the river of fire surrounded the region of the wicked. The gate was so durable that neither men 

nor gods could demolish it, and above it on an iron tower Tisiphone kept guard day and night. From within could bo heard groanings, lashings, grating of iron and clanking of chains (VI 548-558). Rhadamanthus of Crete was the judge of the most wicked souls. After he had compelled all to confess their crimes, Tisiphone shook over the wretched beings her grim snakes and calledup her sister furies.

Within the gate was Tartarus, which sank downward twice as far as the sky extended upward (VI 566-579)

When Aeneas reached the gate to Elysium he sprinkled his body with fresh water and left his offering for Proserpine (VI 636).

Elysium was the abode of the blessed, a region of joy with delightful green retreats and clear skies. There was feasting, sporting on the grass, dancing and singing to Apollo. Trojan heroes with their old fondress were training their shining stoeds and gazing with pride on their armor and chariots. There were patriots priests, poets, and those who helped mankind by useful inventi ons (VI 642-664).

After a fixed period, when winds and water and fire had purged souls from all stains, and a thousand years had been spent in Elysium, the king of the realm sent them to bathe in Lethe's streams of forgetfulness and they were then sent back to the earth to be again clothed with human bodies. (VI 739-75I) 



\section{MERCURY}

Mercury was the son of Jupiter and Maia, and grandson of Atlas (I 297, IV 238) He was born on Mt. Cyllena and sometimes was called Cyllenius (IV 258, VIII 138, IV 252, 276)

Mercury was the messeneer of the gods. He bo und to his feet the golden wings which bore him over land and sea. He carried in his hand a wand with which he called up sould from the dead or sent them in sadness down to Erebus: with it he could give or banish sleep, and drive the winds or cleave the dark clouds (IV 239249).

Evander was a son of Mercury VIII 138

According to Homer it was the duty of Mercury to conduct the souls of the dead to Pluto, but Vergil assigns this duty to Charon (VI 299-304) (Od.XXIV 1-9)

\section{BACCHUS}

Vergil gives little about Bacchus except to use his name as a synonym for wine (I 215, V 77, VIII 181), and describe the revels that were held in his honor. The island of Naxos and Mt. Cithaeron were scenes of Bacchic revels (III 125, IV 303). Women had a prominănt part in such ceremonies. Dido and Amanta when wrought up to madness and wildly roaming city and woods are compared to Bacchanals (IV 300-303, VII 385-389).

The orgies were held every three years, and the participants, in enthusiastic fury claimed they were in- 

spired by Bacchus, raged at the mention of his name, and made the mountains echo with howling (IV 300-303)

In honor of Bacchus virgins spread their hair to the wind, made bare their shoulders and led the dance. They carried a wand entwined with ivy and crowned with a cone. Others clothed themselves in skins, carried javelins, made of ivy-twigs, and made the heavens resound with their shrieks (VII 385-396).

Bacchus was the giver of merriment and the Massic hills were his delight. (I 734, VII 725-726)

PENATES, IARES, VESTA.

When Troy was in flames commanded to Aeneas her sacred things and her penates and told him to go in quest of a city for them. The shade of Hector brought aut from the inner temple the fillets, the powerful Vesta and the eternal fires. (II 293-297). When the fugitives made their escape Anchises carried the sacred things, for Aeneas had recently shed blood and his hand were defiled intil he could wash them in a living stream (II 717-720)

Under Aeneas' care the penates crossed the sea, and at Crete appeared to him as Apollo's messenger. They promised to exalt Aeneas' race to heaven and to give imperial power to his city (III 148-171)

Within the night Aeneas awoke the dormant fires and with the holy cake and full censer paid veneration to his Lares and to hoary Vesta (V 743-745, VIII 543-544) 

When he knew that he had reached the land promised him as a home for his exiled gods, he hailed with joy his faithful Penates. (VII 121, 122, 229, VII 39, I 68, XII 192)

Hecuba and her daughters fled for safety to the altar of the Penates (II 512-513)

The Penates of Dido's family were defiled with $\boxplus i-$ do's blood shed by a brother's hand (IV 2I)

The Penates, Lares, and hoary Vesta were called on to witness a binding oath (IX 258-259).

Vesta is several times mentioned in connection with the Penates and Lares and it was prophesied that she should assist in rendering justice among the Romans. (I 292, II 296, V 744)

\section{FATA AND PARCAE}

The fates had a wide range of power, but were sonetimes disregarded by both men and gods. (IV 225, I 299, V 707, 784, VII 584).

Jove spoke reprovingly to his mother for asking things contrary to fate ( IX 94) Jove determined the fates of men by casting lots, but sometimes he was neutral and left matters entirely to fate. (III 375-X 113) By some higher power things were permitted even to the fates (IX 135). They were not inexorable. (VIII 398, ( 257)

When they summoned a mortal, his, life was at an end. (VI 869, X 472, XI 759, II 433)! 

The dwellers in Elysium were able to read the coming fates (VI 869, VII 123).

The fates baffled the Greeks for a long time, but finally gave Troytto be plundered (II 13, 34, 54).

They preserved Aeneas ( I 546), drove him and the Trojan remnant out of Troy (VII 224, I 32), promised a quiet abode in Latium ( I 205, III 395, VIIf 120, X 67), directedtheir sails (III 9) and after a long training in woes and tears (III 182, XI 97) they led them to Italy (VII 239) and exalted Aeneas to the skies.

\section{(XII 795).}

They did not allow Aeneas to plan and conduct his own life (IV 440): they did not prohibit Juno from molesting the Trojans (V 784): they caused the matrons to set fire to the ships V 656: they forbade the marriage of Aeneas and Dido (IV 440) but favored his union with Iavinia (VII 255, 272)

The Parcae are mentioned in much the same sense as the fates. (I 22, III 379, V 798, IX 107, XII 147, 150)

Their number is not given and they are only once mentioned as holding the threads of man's destiny (X 815 . Parcae legunt fila) 




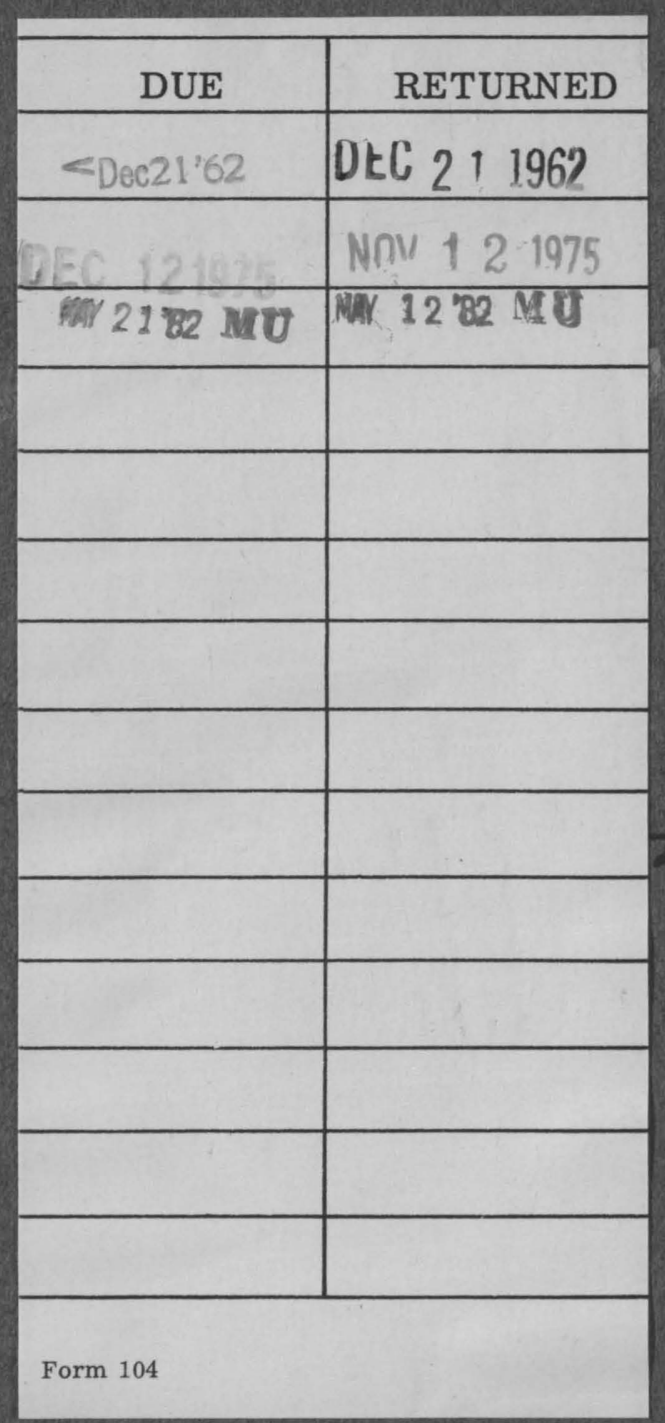




\section{RECEIVEO}


